
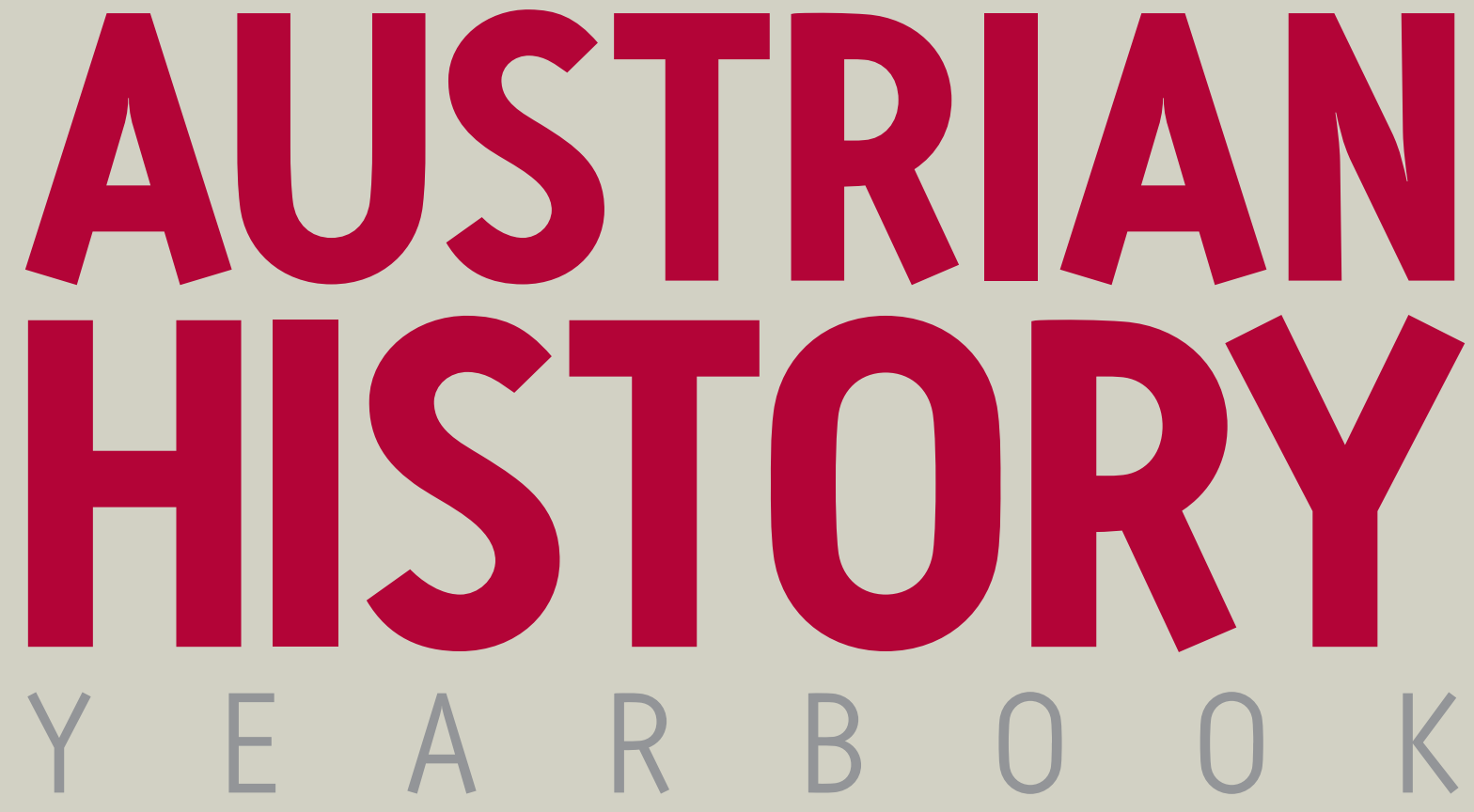

\title{
Volume XLIV.2013
}

ARFAIJA AT OPERAFURBAN.

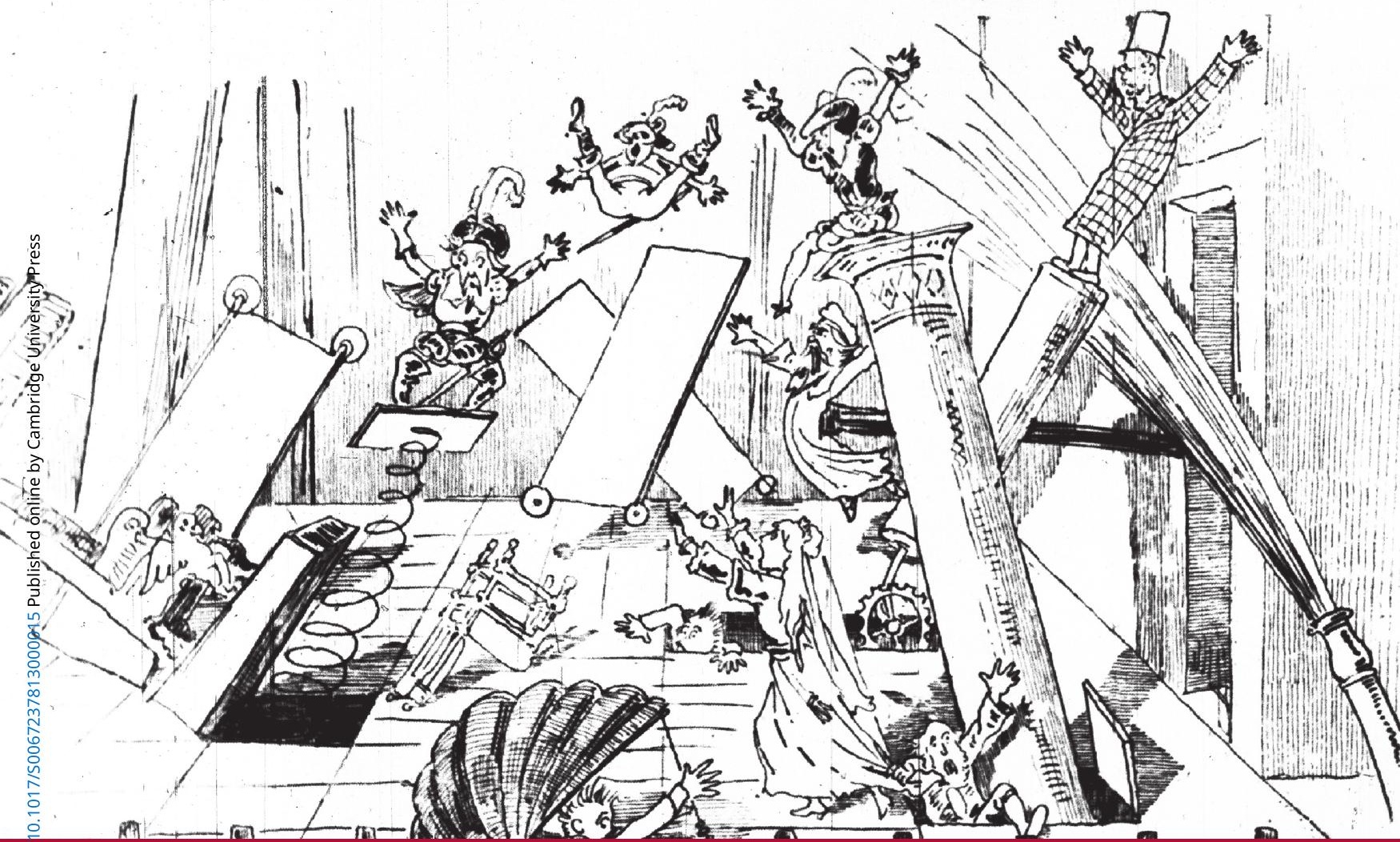

Center for Austrian Studies, University of Minnesota 


\title{
AUSTRIAN HISTORY YEARBOOK
}

\author{
FOUNDED BY R. JOHN RATH
}

\author{
Executive Editor \\ Gary B. Cohen \\ University of Minnesota \\ Associate Editor \\ Margarete Grandner \\ University of Vienna
}

Editor

Pieter M. Judson

Swarthmore College

Book Review Editor

Maureen Healy (From Fall 2012)

Lewis and Clark College

Robert Nemes

Colgate University

\section{Assistant Editor}

Mollie M. Madden

Center for Austrian Studies

\section{Advisory Board}

David F. Good, University of Minnesota Mary Gluck, Brown University

Grete Klingenstein, Karl-Franzens University, Graz

Helmut Konrad, Karl-Franzens University, Graz

Arnold Suppan, University of Vienna

\section{Editorial Board}

Steven Beller, Washington, DC JOHN W. BOYER, University of Chicago Laurence Cole, University of Salzburg ${ }^{*}$ Paul Hanebrink, Rutgers University, New Brunswick

Maureen Healy, Lewis and Clark College Waltraud Heinde, University of Vienna John-Paul Himka, University of Alberta ${ }^{*}$ Jeremy King, Mount Holyoke College ${ }^{*}$ Rebekah Klein-Pejsova, Purdue University

${ }^{*}$ David C. Mengel, Xavier University

${ }^{\star}$ Joseph Patrouch, University of Alberta, Director of the Wirth Institute

Bruce Pauley, University of Central Florida

James Shedel, Georgetown University

Reinhold Wagnleitner, University of Salzburg

${ }^{\star}$ Executive Committee, Society for Austrian and Habsburg History

\section{Correspondents}

Dušan Bataković, Serbian Academy of Sciences; Derek Beales, Cambridge University; Jean-Paul Bled, l'Université Paris IV-Sorbonne; Marina Cattaruzza, University of Bern; Robert Donia, University of Sarajevo; Robert J. W. Evans, Oxford University; Gábor Gyáni, Hungarian Academy of Sciences;

Peter Haslinger, Herder Institute; Yaroslav Hrytsak, L'viv National University;

Eva Kowalské, Slovak Academy of Sciences; Hiroko Mizuno, Osaka University; Jiří Pokorný, Charles University, Prague; Drago Roksandić, University of Zagreb; Peter Thaler, University of Southern Denmark. 
The Austrian History Yearbook is sponsored by the Center for Austrian Studies in cooperation with the Central European History Society and the Society for Austrian and Habsburg History. The editorial offices are at the Center for Austrian Studies, 314 Social Sciences Building, 267 19th Avenue South, University of Minnesota, Minneapolis, MN 55455. Questions concerning articles, book reviews, and other editorial matters should be sent to this address.

From the UK and Europe:

Cambridge University Press

The Edinburgh Building

Shaftesbury Road

Cambridge CB2 8RU/UK

Phone: +44 (0) 1223326070

FAX: +44 (0) 1223325170

E-mail: journals@cambridge.org

\author{
From North America and the Rest of the World: \\ Cambridge University Press \\ Journals Fulfillment Department \\ 100 Brook Hill Drive \\ West Nyack, NY 10994-2133/USA \\ Phone: (800) 872-7423 \\ FAX: 1 (845) 353-4141 \\ E-mail: journals_subscriptions@cambridge.org
}

Questions concerning advertising and other business-related matters should be sent to Cambridge University Press's New York Office.

\section{Aims, Scope, And Guidelines}

The Austrian History Yearbook is a peer-reviewed annual journal for the study of the Habsburg monarchy and the Republic of Austria. It also publishes articles dealing with the other post-1919 successor states if the work has a clear thematic link to the history of the monarchy or the Republic of Austria. It welcomes any submission that has a significant historical dimension or uses historical modes of analysis.

The language of publication is English. The entire text (including quotations, notes, and other supporting material) must be typed double-spaced with generous margins. Notes should be numbered consecutively throughout and placed in a separate section at the end of the text along with any figures or tables. Manuscripts should be no more than thirty pages in length, not counting notes, tables, figures, and other supporting material. Before a submitted article is published, it is refereed by at least two outside scholars.

If you wish to submit an article, please send an electronic copy to the assistant editor at ahy@umn.edu. Electronic copies of final versions of accepted manuscripts must be submitted via e-mail and must be formatted according to Yearbook style guidelines. A style sheet can be obtained from the editors. Please note, if an article contains images, the permissions need to be submitted with the manuscript.

ISSN: 0067-2378 (print) • ISSN: 1558-5255 (online)

Publishing, Advertising, and Subscription Offices: Cambridge University Press, 32 Avenue of the Americas, New York, NY 10013-2473, USA; Cambridge University Press, The Edinburgh Building, Shaftesbury Road, Cambridge CB2 8RU, UK (for UK and elsewhere).

2013 Subscription Information: Austrian History Yearbook (ISSN 0067-2378) is published annually in April by Cambridge University Press, 32 Avenue of the Americas, New York, NY 10013-2473, U.S.A; Cambridge University Press, The Edinburgh Building, Shaftesbury Road, Cambridge CB2 8RU, UK. Annual subscriptions rates for

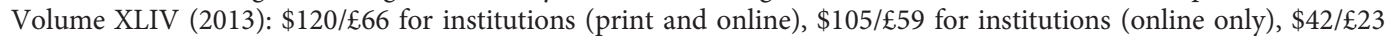

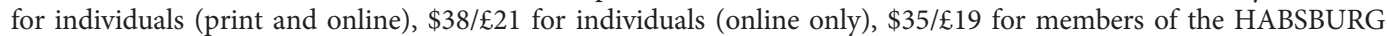
$\mathrm{H}-\mathrm{Net}$ list and the Central European History Society (print only), $£ 16.50$ for Association of Commonwealth Universities Band 2 (print only), \$20/£11 for students and retired professors, and $\$ 120 / £ 66$ for single part. Euro purchases can be made only by credit card. Questions concerning subscriptions and the ordering of back issues should be sent to Cambridge University Press.

(C) Center for Austrian Studies, University of Minnesota 2013

All rights reserved. No part of this publication may be reproduced, in any form or by any means, electronic, photocopying, or otherwise, without permission in writing from Cambridge University Press. Policies, request forms, and contacts are available at: http://www.cambridge.org/rights/permissions/permission.htm

Permission to copy (for users in the USA) is available from the Copyright Clearance Center (CCC), http://www. copyright.com, email: info@copyright.com.

Periodicals postage paid at New York, NY, and additional mailing offices.

Postmaster: Send address changes in the U.S.A. and Canada to: Austrian History Yearbook, Journals Department, Cambridge University Press, 100 Brook Hill Drive, West Nyack, NY 10994-2133, U.S.A. Send address changes elsewhere to: Austrian History Yearbook, Cambridge University Press, The Edinburgh Building, Shaftesbury Road, Cambridge CB2 8RU, UK. 


\section{AUSTRIAN HISTORY YEARBOOK}

\section{Contents}

Editors' Notes

vii

\section{Twenty-Eighth Annual Robert A. Kann Memorial Lecture}

Violence as Identity: Christians and Muslims in Hungary

in the Medieval and Early Modern Period

by Nora Berend

\section{Articles}

The Road to Szigetvár: Ferdinand I’s Defense of His Hungarian Border, 1548-1566 by James Tracy

The Vienna Hofburg between 1835 and 1918-A Residence in the

Conflicting Fields of Art, Politics, and Representation

by Werner Telesko, Richard Kurdiovsky, and Dagmar Sachsenhofer

Austro-German Liberalism and the Coming of the 1867 Compromise:

"Politics Again in Flux"

BY Jonathan Kwan

Scandal at the Opera: Politics, the Press, and the Public at the Inauguration of the Budapest Opera House in 1884 By Markian Prokopovych

Creating Jewish Space: German-Jewish Schools in Moravia by Marsha L. Rozenblit

Power, Partisanship, and the Grid of Democratic Politics: 1907 as the Pivot Point of Modern Austrian History By John W. BOyer

Cubism's Sex: Masculinity and Czech Modernism, 1911-1914 By Thomas OrT 
World War I and Internal Repression: The Case of Major General Nikolaus Cena By IRINA Marin

\section{Historiography and Politics}

The Age of Heroes in Historiography: The Example of Prince Eugene of Savoy BY Filip Š Imetin Š́ggić and Tomislav BranĐolica

Croatia's Politics of the Past during the Tuđman Era (1990-1999)—Old Wine in New Bottles?

By LJILjana Radonic

Remains of a Picnic: Post-Transition Hungary and Its Austro-Hungarian Past by Márton Dornbach

\section{In Memoriam}

Fritz Fellner (1922-2012): In Memoriam

BY JOHN W. BOyeR

Mirjana Gross (1922-2012): In Memoriam

By Filip and Nikolina Šimetin Š́ggić

\section{Book Reviews}

\section{GENERAL}

Adelsgruber, Paulus, Laurie Cohen, and Börries Kuzmany. Getrennt und doch Verbunden: Grenzstädte zwischen Österreich

und Russland 1772-1918.

By Steven Seegel

Cabada, Ladislav. Intellectuals and the Communist Idea:

The Search for a New Way in Czech Lands from 1890 to 1938.

by Gregory C. Ference

Hanisch, Ernst. Der große Illusionist. Otto Bauer (1881-1938).

By JANEK WASSERMAN

Herzog, Hillary Hope. "Vienna is Different": Jewish Writers

in Austria from the Fin de Siècle to the Present.

By Helga Thorson

Johnston, William M. Der österreichische Mensch. Kulturgeschichte der Eigenart Österreichs. вy Roвin OKey

Kuzmany, Börries. Brody. Eine galizische Grenzstadt im langen 19.

Jahrhundert. 
McEwen, Britta. Sexual Knowledge: Feeling, Fact and Social Reform in Vienna, 1900-1934.

By Susan Ingram

Prusin, Alexander V. The Lands Between: Conflict in the East

European Borderlands, 1870-1992.

by Patrice M. Dabrowski

Reill, Dominique Kirchner. Nationalists Who Feared the Nation:

Adriatic Multi-Nationalism in Habsburg Dalmatia, Trieste, and Venice.

By BORUt Klabjan

Winkler, Markus, ed. Presselandschaft in der Bukowina und den

Nachbarregionen.

by Anna-Dorothea Ludewig

TO 1848

Cerman, Ivo, Rita Kruger, and Susan Reynolds, eds. The Enlightenment in Bohemia: Religion, Morality, and Multiculturalism.

by Heather Morrison

David, Zdeněk V. Realism, Tolerance \& Liberalism in the Czech

National Awakening: Legacies of the Bohemian Reformation.

By Kurt F. Strasser

Hecht, Louise. Ein jüdischer Aufklärer in Böhmen: Der Pädagoge und Reformer Peter Beer (1758-1838).

by Gaelle Vassogne

Iveljić, Iskra. Očevi i sinovi. Privredna elita Zagreba u drugoj polovici 19. stoljeća.

Petrungaro, Stefano. Kamenje i puške. Društveni protest na hrvatskom selu krajem XIX. stoljeća.

BY Filip Šimetin Š́guić

Kejř, Jiř́. Die mittelalterlichen Städte in den böhmischen Ländern.

Gründung-Verfassung-Entwicklung.

By James Palmitessa

Miller, Michael Laurence. Rabbis and Revolution: The Jews of Moravia in the Age of Emancipation. By Glenn Dynner

Mortimer, Geoff. Wallenstein: The Enigma of the Thirty Years War. By Paula Sutter Fichtner

Patrouch, Joseph F. Queen's Apprentice: Archduchess Elizabeth, Empress

Maria, the Habsburgs, and the Holy Roman Empire, 1554-1569. By Hamish ScotT

Wolf, Kenneth Baxter, ed. and trans. The Life and Afterlife of

St. Elizabeth of Hungary: Testimony from Her Canonization Hearings. BY INGRID WÜRTH

$1848-1918$

Horel, Catherine, ed. 1908, l'annexion de la Bosnie-Herzégovine, cent ans après.

By IgOr TCHOUKarine 
Long, Christopher. The Looshaus. by Kimberly Elman Zarecor

Malfèr, Stefan. Kaiserjubiläum und Kreuzesfrömmigkeit. Habsburgische 'Pietas Austriaca' in den Glasfenstern der Pfarrkirche zum Heiligen Laurentius in Wien-Breitensee. Mit Farbtafeln von Herbert Stöcher. by Peter Urbanitsch

Oxaal, Ivar. On the Trail to Wittgenstein's Hut: The Historical Background of the Tractatus Logico-Philosophicus. by Michael Gubser

Szívós, Erika. Social History of Fine Arts in Hungary, 1867-1918. By Michelle Facos

Tonezzer, Elena. Il corpo, il confine, la patria. Associazionismo sportivo in Trentino (1870-1914). by Fiammetta Balestracci

Zimmermann, Susan. Divide, Provide, and Rule: An Integrative History of Poverty Policy, Social Policy, and Social Reform in Hungary under the Habsburg Monarchy. By Gábor Gyáni

SINCE 1918

Benziger, Karl P. Imre Nagy. Martyr of the Nation: Contested History, Legitimacy, and Popular Memory in Hungary. by Joanna Granville

Cornelius, Deborah S. Hungary in World War II: Caught in the Cauldron. By Leslie M. Waters

Cornwall, Mark. The Devil's Wall: The Nationalist Youth Mission of Heinz Rutha. by Eva Pfanzelter

Fülöp, Mihály. The Unfinished Peace: The Council of Foreign Ministers and the Hungarian Peace Treaty of 1947. by Daniel M. Pennell

Greble, Emily. Sarajevo, 1941-1945: Muslims, Christians and Jews in Hitler's Europe. by Christian Axboe Nielsen

Haynes, Rebecca and Martyn Rady, eds. In the Shadow of Hitler: Personalities of the Right in Central and Eastern Europe. By Heidi Hein-Kircher

Levi, Erik. Mozart and the Nazis: How the Third Reich Abused a Cultural Icon. By Michael Cherlin

Thorpe, Julie. Pan-Germanism and the Austrofascist State, 1933-38. By Johannes Koll

Trümpi, Fritz. Politisierte Orchester. Die Wiener Philharmoniker und das Berliner Philharmonische Orchester im Nationalsozialismus. 